PROBLEMS

OF EDUCATION

IN THE $21^{\text {st }}$ CENTURY

Volume 66, 2015

\section{A CANADIAN TEACHER'S PERCEIVED AUTONOMY AND SELF-CONFIDENCE IN THE MIDST OF AN EDUCATIONAL REFORM}

\author{
Audrey Paradis, Sonja Lutovac, Raimo Kaasila \\ University of Oulu, Finland \\ E-mail: audrey.paradis@student.oulu.fi, sonja.lutovac@triera.net, \\ raimo.kaasila@oulu.fi
}

\begin{abstract}
Autonomy is essential for teachers' commitment, satisfaction and retention. However, teacher autonomy is consistently being reduced in the current era of reforms and the sharing of global policies. In this narrative case study, the account of one Canadian teacher (Nora) was examined in relation to how an educational reform influenced her work life in terms of her perceived autonomy and self-confidence. The relation between teacher autonomy and self-confidence was addressed, and the ramifications prompted by the fluctuations in both constructs. The findings suggest that the relationship between Nora's perceptions of teacher's professional autonomy and her self-confidence is complex. Nora's self-confidence was strongly related to her perceived autonomy and the reduction of autonomy triggered significant downward spiralling, leading to isolation. Some discussion on the possible ways to help teachers break this downward spiralling is provided. Finally, this research broadens the collection of stories by teachers on challenges introduced by educational reform and gives voice to teachers suffering in isolation.
\end{abstract}

Key words: educational reform, narrative inquiry, perceived self-confidence, teacher autonomy, teacher isolation.

\title{
Introduction
}

The concept of 'autonomy' is used in a broad fashion, not only with philosophical, but also with political, cultural and ideological outlooks. An emotional undertone is affixed to autonomy, connoting it often implications of liberty, freedom, independence - which can in turn establish autonomy as an individual and a collective source of hope and aspiration. Autonomy is of utmost importance for teachers (Strong \& Yoshida, 2014) and an essential element to their job commitment, efficiency, satisfaction and retention (Ingersoll, 2001; Pearson \& Hall, 1993; Yu-hong \& Ting, 2012). However, during the current era, teacher autonomy is consistently being eroded by reforms and global policies of increased accountability and privatization (Benson, 2007, 2010: Perryman, Ball, Maguire, \& Braun, 2011). Day (2002), Helgøy and Homme (2007) and Pearson and Moomaw (2005), have discussed the development and implementation of reforms in relation to teacher autonomy. The importance of autonomy for teachers and its fluctuations often brought by individuals outside the classroom have more ramifications than can be anticipated, and which can currently be found in the literature (Day, 2002; Sachs, 2001).

Academic literature links teacher autonomy with many other concepts: amongst them, self-confidence, which is of particular interest in this research. Teacher's self-confidence has been considered as a condition for teacher's sense of autonomy (Govier, 1993; Littlewood, 1996; Spratt, Humphreys \& Chan, 2002). This suggests a unidirectional relation between teach- 
er autonomy and self-confidence. Arguably, there is a gap in the literature regarding alternative views on this relation. The degree of autonomy teachers have may influence their self-confidence with associated ramifications. This issue requires more attention, as the complex entanglement between the two concepts may trigger significant downward spiralling, leading even to teachers leaving the profession. It is important to have a deeper look at the intertwining of the two concepts, to make clear that an imbalance of the two concepts or a reduction of one of the concepts has repercussion on the other one.

This narrative case study aims to give voice to teachers who may be suffering, being caught in a downward spiralling due to an impaired sense of autonomy in the midst of educational reform. One Canadian high school mathematics teacher's narrative is analysed, as it is particularly information rich (Patton, 1990). The analysis regards her teaching life, looking back at one major educational reform implemented in the province of Québec in the early 2000s, and the meaning of the reform for her then and after. This reform (Le Renouveau Pédagogique) affected all levels of high school in all subject matters, and brought radical changes in many spheres of action for teachers. In brief, there was a paradigm shift in the ways schooling was conceptualised - from schooling to teach (based on objectives for teachers to cover) to schooling for learning (based on competencies for students to gain). This implied major ideological changes in most aspects of the teachers' work for which they were not sufficiently prepared or ready (Bissonnette, Gauthier, \& Richard, 2005). Many teachers liked several new goals and ideas from the reform, but it was challenging for teachers to adopt it and adapt to it in a short time. School administrations were in parts responsible for a smooth implementation of the reform. They had some latitude in the rigor with which the reform had to be implemented and observed.

Nora narrated a story of how the reform influenced her work life in many ways, but especially in terms of her perceptions of autonomy and self-confidence. This rich data allowed for a deeper look into the complex relations between the teacher's perceptions of autonomy entangled with her self-confidence, as well as at the ramifications prompted by the fluctuations in both autonomy and self-confidence. This data also allowed for a contribution to the discussion of mathematics teachers' perceived autonomy, as too little is to be found with regard to this issue in the academic literature (Blömeke \& Klein, 2013; Robertson \& Jones, 2013; Strong \& Yoshida, 2014). Nonetheless, mathematics teaching often requires additional autonomy from the teachers' perspective (Blömeke \& Klein, 2013).

The following research questions are thus addressed: How does the teacher's perceived autonomy and self-confidence fluctuate in the midst of educational reform? What are the possible ramifications of these fluctuations for a teacher? Ultimately, by telling Nora's story, the aim is to broaden the collection of teachers' stories on the challenges introduced by educational reforms. This article may serve people working in education by helping them to understand the ramifications of reforms and of their implementation, as well as comprehend what issues may lie behind closed classroom doors. This research may also serve as a therapeutic or emancipating read for teachers like Nora, who in difficult situations imposed on them, suffer in isolation.

\section{Theoretical Perspective}

\section{Teacher's Perceived Autonomy}

Autonomy is highly valued and desired in western social contexts (Berka, 2000; Dworkin, 1988; Smith \& Ushioda, 2009) and is increasingly looked as a "universal moral good" (Shaw 2008, p. 188) - as something teachers think they are entitled to. It is undeniably of importance in educational contexts. Teachers seem to want more autonomy, regardless of the amount they already have (Strong \& Yoshida, 2014). Since teachers want more autonomy de- 
Audrey PARADIS, Sonja LUTOVAC, Raimo KAASILA. A Canadian teacher's perceived autonomy and self-confidence in the midst of an educational reform

PROBLEMS

OF EDUCATION

IN THE $21^{\text {st }}$ CENTURY Volume 66, 2015

spite the starting point, their perceptions of autonomy may be symptomatic of what they are willing to do to obtain more autonomy or to keep what they already have. In that case, what happens when autonomy is taken away? One can imagine that their job commitment, efficiency and satisfaction decrease, but what do teachers do then?

The concept of teacher autonomy is vague and has been defined in the literature in many ways (Aoki, 2000; McGrath, 2000; Strong \& Yoshida 2014). The detailed definition by Gwaltney (2012) is applied in this research, stating that teacher autonomy is "the degree to which teaching provides substantial freedom, independence, power, and discretion to participate in scheduling, selecting, and executing administrative, instructional, and socialization and sorting activities both in the classroom and in the school organization at large" (p. 22). This definition includes important elements that are provided to teachers in order to exercise their professional autonomy, such as freedom, independence, power and discretion. It does not, however, indicate where those elements come from and who/what grants those elements to the teacher. Benson (2010) offers an answer by arguing that freedom is necessary for teacher autonomy to be realised. This means that teachers are required to free themselves from internal and external constraints. Further, psychological capacities of teachers to be freed from internal constraints can be related to teachers' capacities for self-confidence (Benson, 2010) and can highlight the vigour teacher has in order to take control of the situation (Benson, 2008). The literature on teacher autonomy in the context of educational reform shows that the freedom from external constraints can be granted to teachers from their environment, policies and other people (who may exercise power over them) with whom teachers are in relationship. Looking at those external constraints in teachers' contexts can provide an insight in how teachers are perceived and treated by policies and superiors, and whether they are trusted and considered as professionals. Helgøy \& Homme (2007), and Pearson \& Moomaw (2005) described how increasing teacher autonomy enhances their sense of empowerment and professionalism. Pearson and Moomaw (2005) added that teachers' sense of empowerment and professionalism are enhanced when teachers are trusted and given some powers in the decisions made with the development and implementation of reforms. They also say that, for successful reform, initiatives and implementations, teacher autonomy is critical and should be thoroughly considered.

\section{Teacher's Self-confidence}

Generally speaking, self-confidence is defined in the literature as a positive/negative self-evaluation or perception of the self (Chuang, Cheng, Chang \& Chiang, 2013; Tett \& Maclachlan, 2007). It is usually related to the degree of certainty directed towards one's general capabilities, personalities or abilities (Morony, Kleitman \& Stankov, 2013). The concept of selfconfidence can be examined from the individual and social perspective (Morony, Kleitman \& Stankov, 2013; Tett \& Maclachlan, 2007). Individual self-confidence can be influenced by the person him/herself, i.e. being successful or not in actions that constitute one's experience. Selfconfidence can be influenced by many social factors; for example, a teacher's self-confidence could be enhanced by the support of the school community or eroded by its judgement, making teachers feel either empowered or vulnerable (Kelchtermans, 1996). Tett and Maclachlan (2007) go further and discuss the strengthening of self-confidence through social interactions, adding that support and encouragements from peers and superiors contribute to the enhancing of one's self-confidence.

\section{The Relationship between Teacher's Perceived Autonomy and Self-confidence}

Literature discusses in general terms that self-confidence is a precondition for autonomy (Govier, 1993; Spratt, Humphreys \& Chan, 2002). Littlewood (1996) goes further by explain- 
ing that autonomy is a capacity to carry out choices, depending on the two main components of ability and willingness. He explains that the ability to make autonomous decisions is based

PROBLEMS

OF EDUCATION

IN THE $21^{\text {st }}$ CENTURY

Volume 66,2015 on one's knowledge and skills, while willingness is based on one's self-confidence and motivation. Arguably and inversely, teacher's perceptions of autonomy can influence his/her selfconfidence. This can be understood in the constantly changing local and global educational politics, and contexts play a role in teacher's self-confidence and especially autonomy. The growing phenomenon of policy borrowing in education often brings reforms that are imposed on teachers. Even though research addressed the trends in reforms, less attention seems to be confined to teacher autonomy and how reforms influence it (Helgøy \& Homme, 2007). Day (2002) suggests that teacher autonomy is being increasingly eroded as new limits and measures are taken to determine and monitor the achievements of students and teachers. The author (2002) further suggests that managers increasingly shape reforms instead of educators, and that takes autonomy away from teachers. In this light, Sachs (2001) claims that teachers are now being deskilled, and have more work to do with fewer resources. Kelchtermans (1996) warns about the external pressures put on teachers when parents, superiors, colleagues or new policies inflict unrealistic expectations on them. The author (1996) further explains that such pressures shake teachers' self-confidence and make them feel vulnerable.

\section{Methodology of Research}

\section{Research Participant and Data Collection}

The objective here was to have a look at the perceptions of autonomy for teachers, in relation to their self-confidence. The method that allows for a thorough appraisal of those concepts, and the one chosen in this research, is the narrative method (Strong \& Yoshida, 2014). At the outset of 2014, the first author of the article collected the data for her doctoral dissertation. She interviewed four Canadian mathematics high school teachers about their perceived autonomy and self-confidence. Due to the particular richness of one specific interview (Nora's), this singular case was chosen for deeper analysis, supported by a critical case strategy (Patton, 1990). The precepts preferred for narrative interview were followed mainly from Connelly and Clandinin (1990), and Kaasila (2007). The interview was carried out in French, the audio being recorded with the participant's agreement. For the purposes of this research, the data was later translated into English. Nora was asked to tell her stories freely under the seal of confidentiality. She provided detailed narratives about her autonomy in relation to her self-confidence, referring to the educational reform.

Prior to the interview, the research participant had received an informed consent, an explanation of the research, and was asked to draw her storyline in a graph. The graph inquired about the level of self-confidence as a mathematics teacher over the course of her teaching career. This method was inspired by Beijaard's (1995) storylines. The interview began with the participant explaining her graph of teacher's self-confidence levels over the years. This was a fruitful beginning, as it encouraged Nora to talk about her life story and its turning points. The graph also provided an opportunity for her to reflect on her professional life prior to the interview in a way she may not have reflected on it before. Once Nora told her story, she was asked for more details. The main themes investigated were working environment, turning points in levels of autonomy (reform), changes in autonomy/self-confidence over the years, and latitude in facing the curriculum and evaluation. Nora's case was chosen in order to exemplify the ramifications deriving from the many difficult situations that teachers face within the changing contexts. 
Audrey PARADIS, Sonja LUTOVAC, Raimo KAASILA. A Canadian teacher's perceived autonomy and self-confidence in the midst of an educational reform

OF EDUCATION

IN THE $21^{\text {st }}$ CENTURY

Volume 66,2015

Data Analysis

The data was analysed holistically by means of narrative analysis (Lieblich, TuvalMashiach \& Zilber, 1998; Lutovac \& Kaasila, 2010; Polkinghorne, 1995). Nora's story of her perceived autonomy and self-confidence in the midst of the educational reform was emplotted. The graph Nora drew about her self-confidence over her teaching years was a very useful tool to refer to when the emplotment of her story was elaborated. It enabled the observation of when and what influenced the self-confidence. First, segments were selected from the interview data where Nora narrates issues of autonomy and self-confidence, and the ones related to the reform. Secondly, data was arranged chronologically in order to provide an explanation for the meaning that the reform had for Nora. Thirdly, the data was interpreted by taking into account Nora's larger narrative, but also the knowledge of the context in which she operated. Finally, the theoretical framework also provided a lens for the interpretations. All in all, the emplotment was useful for observing changes in Nora's perceptions of autonomy and self-confidence as the years went by.

\section{Results of Research}

Nora teaches mathematics to the junior grades of a public high school. She has more than 20 years of teaching experience, a passion for teaching, and is dedicated to her students. Looking back at her teaching career and speaking about how it was over the years, Nora had acknowledged that her perceptions of autonomy and her self-confidence are not in a vacuum and that they have been altered several times by many occurrences. Nora's interview starts with her display of self-confidence, as she believes she is a competent mathematics teacher. She said: "Yes, I think I am a good math teacher..." She goes back in time to describe why she became a mathematics teacher. Being a mathematics teacher seem to have an influence on her self-confidence:

"I am under the impression that math (...) looks more professional because it's a more rigorous subject matter (...) Parents will have more confidence in the comments of the math teachers (...) [comments to parents] will have more value than if it was coming from another [subject] teacher (...) [students] will admire your work more [if you are a mathematics teacher](...) I look more... adequate I think, to educate from the fact that I teach math"

Nora appears to take pride in the fact that she teaches mathematics. She has a positive perception of herself just from the subject matter she teaches. Her confidence is enhanced internally by her positive experiences and externally by positive feedback from the environment. This likely contributed to the fact that Nora considers herself as a 'good math teacher'.

In the early $2000 \mathrm{~s}$, the major provincial reform was implemented, introducing at the same time one of the biggest turning points in Nora's career and affecting both her self-confidence and her perceived autonomy.

\footnotetext{
"Before the reform, we were more autonomous (...) before we could evaluate more freely with exams and it was better (...) before the reform, there was not so many changes happening, and the implementation was not as drastic (...) before, listen we could do our job, we did our teaching hours [and that was it]. Now we must write down [all details of many other extra tasks](...) Your schedule is full you know."
}

Nora perceived her autonomy to be greater before the implementation of the reform. She 
Audrey PARADIS, Sonja LUTOVAC, Raimo KAASILA. A Canadian teacher's perceived autonomy and self-confidence in the midst of an educational reform

claims that at this point, autonomy was taken away from teachers in many ways. One of them is evident in how the government develops evaluations that must be implemented by teachers. This exemplifies the autonomy taken from teachers to be given back to managers. The lack of freedom from external constraints seems to impair Nora's autonomy, affecting areas of teacher autonomy. According to Nora, the reform and the way it was implemented not only reduced the autonomy for teachers but also influenced her self-confidence. Nora pointed on her graph of self-confidence where the sharpest drop was seen over the years and explained:

"and then here, it's the reform (...) the reform, the administration team that brought it, and that kind of atmosphere also, the feel [environment of the school]"

It was clear from Nora's narrative that the reform - especially the administration that implemented it - had a major impact on the diminution of Nora's self-confidence as well as the perceptions of her autonomy:

"with the reform, we now have to evaluate students with rubrics [provided by the government] (...) moreover with this admin team which is crazy about the reform, then they would verify if you were really doing your things properly. And you are watched, [admin team] are allowed to you cut [cut your pay]. It's enormous the change that occurred (...) I had lost my autonomy regarding my means to teach and to evaluate my students. I even considered changing career..."

Nora related that the administration's implementation of the educational reform is slowly taking away teachers' freedom, which makes for a difficult relationship between teachers and the administration team. Nora's vulnerability due to the loss of autonomy even brought on thoughts of leaving the profession, showcasing here how desired and important autonomy is for her. From Nora's excerpts, it is suggested that her administration micro-manages the teachers and holds them accountable. Those external constraints provide an insight on how teachers are not necessarily trusted and treated as professionals. This mistrust impairs Nora's ability to be autonomous. When autonomy is taken away from her, Nora starts to question her ways to work and her own self-worth as a professional - shaking her self-confidence when she examines her own abilities and capacities:

"if you did not believe in [the reform], if you weren't really doing it, then all in a sudden you were no longer a good teacher (...) The admin denigrates you, your colleagues are avoiding you, everyone in their little corners following the 'grand plan' or pretend to follow it. It truly feels like they are cutting ours wings off (...) it is then I started to doubt even my own teaching ways/practices (...) you have so much to do [with added tasks and fewer resources] so you get overwhelmed and so you have less self-confidence, you make less successful courses, so it gives less confidence"

Nora was in a situation where individual and social negative perceptions impaired her confidence about being 'a good math teacher'. With reduced self-confidence, it is difficult to gain or keep autonomy. It can be understood here that Nora's limited self-confidence was aggravated by the judgement of her colleagues. With this negative outlook, internal capacities for autonomy are hindered, which makes it difficult to behave reactively to the reduction of autonomy. Nora explained how the fluctuation of her autonomy influenced her self-confidence:

\footnotetext{
"The biggest impact from [the change of] my autonomy level was the feeling of exclusion, depreciation and loss of self-confidence. You are under the impression that you no longer know how to do the thing you have been doing for a long time, and that you have made a mistake and you constantly question yourself. "
}

PROBLEMS

OF EDUCATION

IN THE $21^{\text {st }}$ CENTURY

Volume 66, 2015 
Audrey PARADIS, Sonja LUTOVAC, Raimo KAASILA. A Canadian teacher's perceived autonomy and self-confidence in the midst of an educational reform

PROBLEMS

OF EDUCATION

IN THE $21^{\text {st }}$ CENTURY

Volume 66, 2015

The contrast to the link addressed in the literature, i.e. the influence of teacher's self-confidence on teacher autonomy (Nora's upper excerpt), presents a different relation between the two constructs. The diminution of Nora's perceived autonomy influenced her self-confidence negatively. Inversely, low self-confidence hinders internal capacities to gain or keep autonomy - which may decrease even more with no counteraction. The more the perceived autonomy decreases, the more self-confidence suffers in unsupportive context. Feeling trapped in this negative cycle of little self-confidence and decreasing perceptions of autonomy, which is referred to as downward spiralling, Nora hides to feel that she can keep the autonomy she has, and/or feels like she can be more autonomous on her own:

"People would point at the ones not applying the reform, me included, and I felt controlled. I also felt less good of a teacher. (...) I was hiding and I was using [grades instead of letters] anyways, but I could not tell anyone (...) I kind of excluded myself, I installed myself in another staff room alone - without any other colleague, speaking less you get less confident."

Nora's autonomy was diminished as the control over her ways and work grew. Her selfconfidence was also impaired by the diminution of the autonomy imposed upon her by the implementation of the reform. It was difficult for her to be alienated and judged by others, and her vulnerability led her to exclude herself from this judgement and control. Even if it is possible to find more peace this way, the excerpt suggests that this isolation did not help Nora's selfconfidence. This exemplifies how low perceptions of teacher autonomy can be symptomatic of what a teacher is willing to do in order to be - or at least feel - autonomous.

Reflecting on the happenings in her school context, Nora pointed at her graph of selfconfidence saying: "So why [self-confidence] started to go back up here [on the graph] it's because (...) [grades and averages] came back." Nora explains that after acknowledging the difficulties teachers had with the implementation of the reform, the administration made some adjustments. They gave some autonomy back to teachers. It is noticeable here that when autonomy was to a certain extent given (back) to Nora, it enhanced her self-confidence, validating the work she does and reinforcing her self-confidence. Arguably, it is again displayed that Nora's autonomy has an influence on her self-confidence, and it signals more trust and feeling of professionalism given to teachers. Nora was critical about the reform, but she could recognise some positive aspects that it brought to her teaching:

"There are certain things that I appreciated from the reform like give to students problematic situations, where the student, one group would have a task to accomplish and they have to go until a certain point. (...) Now, they [problematic situations] are less difficult also, and we got them more used to it too so this is nice."

Nora thus displayed some openness towards the reform and its implementation, despite some negative aspects of the reform on her career. Nora was against, for example, the imposed evaluation and the micro-management. However, there were some aspects of the reform that did make sense to Nora, especially those that benefited her students. For this reason, she was pleased to implement them.

Finally, after roughly a decade since the implementation of the reform, Nora tells about her current situation regarding her self-confidence and her perceptions of autonomy:

"I can make my own projects only because I go for it and don't necessarily ask as this autonomy is not handed 'freely' to us and is sometimes discouraging (...) I'm pretty stubborn so my autonomy you know, I do what I want in my classroom you know. And I don't tell anyone..." 
Nora's description shows how she has become over the years, and how she operates now with the situations she has lived in. It is evident that for her, autonomy is still desired. The excerpt also suggests that Nora has self-confidence when she spoke of certainty, initiative and vigour to do what she pleases in her classroom. Nowadays, she also shows internal capacities for autonomy, as she does not explicitly put constraints on herself preventing her from taking autonomy that is not easily granted to her. The external constraints are still present, but Nora finds ways to act autonomously despite them. On the other hand, the utterance "I don't tell anyone" seems to indicate that Nora continues to isolate herself in order to be more 'autonomous'.

Over the course of her career, the self-confidence Nora expressed in the beginning undergoes drops, especially with the implementation of the reform. Her autonomy was hindered, which in turn seemed to hinder her self-confidence even more, inducing the downward spiralling leading to isolation. When some revisions were done to the reform granting some autonomy back to teachers, Nora's self-confidence improvement is noticeable in some way. However, even after the revisions, the results suggest that Nora's autonomy could still be better and that she kept some of the mechanisms acquired before, such as hiding behind the closed door of her classroom to be in peace.

\section{Discussion}

From the results, it is evident that the relationship between Nora's perceptions of her autonomy and self-confidence is complex, and that each construct is changing over the course of her career. The emplotment of Nora's story allowed to retrospectively showcase Nora's perceived autonomy and self-confidence at different times - before, during, and after the reform - in a fluid way. Nora's narrative indicates that the reform had an impact on her self-confidence as well as on her perceptions of autonomy. Not only the relation between teacher autonomy and self-confidence in the midst of a major education reform was addressed, but also the ramifications prompted by the fluctuations in both constructs. Nora's self-confidence seems to be related to her perceptions of autonomy, and the reduction of both during the reform triggered significant downward spiralling. Trying to navigate with her decreasing autonomy entangled with her decreasing self-confidence, Nora ended up hiding and isolating herself, while also being alienated by others. Though she does not necessarily feel content in this isolated situation, this is the price she is willing to pay in order to feel autonomous. The results demonstrate that Nora's story was particularly rich, supporting the selection of her case for study. Among all stories heard at first, Nora's was critically selected as it was the one contributing the most towards understanding how perceptions of autonomy and self-confidence are entangled in the midst of an educational reform.

Drawing on Benson (2010), Nora's perceptions of autonomy at times are hindered both by her self-confidence (internal constraints to autonomy) and her school context with the reform (external constraints to autonomy). Considering that diminished self-confidence can yield diminished autonomy (Govier, 1993; Spratt, Humphreys \& Chan, 2002), and in turn diminished autonomy can yield diminished self-confidence (on the basis of Nora's story), the delicate and complex entanglement of the two concepts can be appreciated. The results suggest that, depending on the circumstances, Nora could take actions on her autonomy regardless of what her administration would say. This demonstrates that it is possible, yet not facilitated to have internal capacities to take autonomy even without the support of external capacities. However, these circumstances do not necessarily yield to healthy outcomes. The kind of isolation Nora placed herself in, while helpful in terms of her coping with the feelings of being controlled and judged, is also unhealthy if it is the only way for her to feel autonomous.

The so-called 'closed-door autonomy' (Brooks, Hughes \& Brooks, 2008) Nora gains does not serve in helping her become more efficient, supported or empowered. It serves more 
Audrey PARADIS, Sonja LUTOVAC, Raimo KAASILA. A Canadian teacher's perceived autonomy and self-confidence in the midst of an educational reform

PROBLEMS

OF EDUCATION

IN THE $21^{\text {st }}$ CENTURY

Volume 66, 2015

as a place of escape so that she can be left in peace. Clearly, isolation is a problem for Nora, as it is one way for her to endure her context and the external constraints put on her by her administration team and their implementation of the reform. The results indicate that isolation had considerable impacts on Nora's self-confidence. Arguably, isolation can be a way for teachers to feel illusorily autonomous. If teachers feel too little support and cohesion with their community, the desire to hide grows stronger to acquire such 'closed-door autonomy', which can be a mistaken perception of autonomy. It is important to point out that not all isolation is detrimental: for example, some teachers may isolate themselves to enable undisturbed work in efforts to prepare their teaching. Isolation becomes harmful when teachers choose it as a means of survival (Brooks, Hughes \& Brooks, 2008) - as a means to avoid pressures and conflicts, in the manner of Nora. Therefore, it is arguably, the case that autonomy should be differentiated from isolation. It should be understood as a construct that empowers teachers and encourages their development, and is enriched by collegial interactions and meaningful feedback (see also Pearson \& Moomaw, 2005). Similarly, Hargreaves and Goodson (1996) suggest that self-protective autonomy should be replaced by the open and collaborative work of teachers, with all the important actors involved in the students' learning journeys.

Even if often large-scale reforms raise enthusiasm, they also frequently fail to obtain commitment from teachers (Hargreaves, 2004). This is mainly due to the lack of input being asked from teachers (Pearson \& Moomaw, 2005), the pressures they feel from the implementation, and the lack of support they receive throughout the changes. Hargreaves (2004) also noted that such kinds of pressures for reforms often take teachers' attention away from students and toward the administration. In line with Helgøy and Homme (2007), Nora's case shows that reformers should be more alert also to issues such as downward spiralling and isolation on the part of teachers. If such issues are ignored or not properly addressed, reformers are not only at risk of sabotaging reforms and their implementation (Pearson \& Moomaw, 2005), but risk seeing teachers suffering from them - and ultimately students suffering as well. It is meaningful to acknowledge that for Nora, the implementation of a reform was the most significant occurrence transforming her teacher's self-confidence and perceptions of autonomy. However, such transformations could also be sparked by teachers' attitudes, personalities, cultures, experiences and beliefs (see, e.g., Yu-hong \& Ting, 2012). The downward spiralling for teachers could be triggered, for example, by changes in the administration team, moving to a new school, being assigned new courses to teach, or personal life situations impairing the capacities, abilities or vigour to work. It is imperative to give a voice to suffering teachers with the aim of better understanding the possible impacts of reforms on teacher's perceived autonomy and selfconfidence; thus, this research could be considered as a therapeutic and empowering read for teachers finding themselves stranded in various situations. Additionally, there was no attempt to generalise the findings to include all mathematics teachers involved in reforms - Nora's case solely illustrated the ways reform may be reflected in teachers' views of their autonomy and self-confidence.

Considering that complex relationship between teacher autonomy and self-confidence, one can wonder how teachers can free themselves from the downward spiralling they may be caught in. When both internal and external capacities for autonomy are low, along with low self-confidence and little support, breaking free is not an easy task. Actions can be taken by teachers themselves or they may be external - for example, from administration teams concerned with the well-being of their teachers. One first step towards breaking the cycle could be for teachers to acknowledge their issues, such as the aforementioned downward spiralling and isolation. Talking to trustworthy colleagues, superiors or union members could be a step leading them out of their isolation. If teachers were more encouraged and trusted as devoted and responsible professionals (Pearson \& Moomaw, 2005), supported in classroom management and reform implementation, their self-confidence would be enhanced - which could also enhance 
Audrey PARADIS, Sonja LUTOVAC, Raimo KAASILA. A Canadian teacher's perceived autonomy and self-confidence in the midst of an educational reform

their perceptions of autonomy, hence their job satisfaction, motivation and efficiency (Ingersoll, 2001; Pearson \& Hall, 1993; Yu-hong \& Ting, 2012). If teachers were granted more autonomy, that could lead - as in Nora's case - to better self-confidence, which creates better and healthier working situations for teaching professionals.

\section{Conclusions}

On the basis of the results of this research, here are some concluding remarks. First, both teacher autonomy and self-confidence should be supported as much as possible while encouraging evolving teaching practices. Both teacher autonomy and self-confidence should be taken into close consideration when elaborating and especially when implementing new policies and reforms. If teacher input is considered and if support is offered, the need to hide may subside and less teacher isolation may take place. Second, isolation should, in any case, be assessed. The reasons why teachers choose to work behind closed doors may determine their need for support and their levels of self-confidence and perceived autonomy. Confident and supported teachers are more likely to yield the best results. If the needs of teachers for autonomy and support are more observed by administrators and policy makers, teacher turnover may decrease - especially for mathematics teachers.

\section{References}

Aoki, N. (2000). Aspects of teacher autonomy: Capacity, freedom and responsibility. Paper presented at 2000 Hong Kong University of Science and Technology Language Centre Conference.

Beijaard, D. (1995). Teachers' prior experiences and actual perceptions of professional identity. Teachers and Teaching: Theory and Practice, 1 (2), 281-294.

Benson, P. (2007). Autonomy in language teaching and learning. Language Teaching, 40 (01), 21-40.

Benson, P. (2008). Teachers' and learners' perspectives on autonomy. In T. Lamb \& H. Reinders (Eds.), Learner and Teacher Autonomy: Concepts, realities, and response (Vol.1, pp. 1-15). Amsterdam: John Benjamins Publishing.

Benson, P. (2010). Teacher education and teacher autonomy: Creating spaces for experimentation in secondary school English language teaching. Language Teaching Research, 14 (3), 259-275.

Berka, W. (2000). The legal and philosophical meaning of autonomy in education. In W. Berka, J. De Groof \& H. Penneman (Eds.), Autonomy in education. Yearbook of the European Association for Educational Law and Policy (Vol. 3, pp. 3-10). The Hague: Kluwer Law International.

Bissonnette, S., Gauthier, C., \& Richard, M. (2005). Échec scolaire et réforme éducative: quand les solutions proposées deviennent la source du problème [Scholar failure and educational reform: when the proposed solutions become the source of the problem]. Laval: Presses Universite Laval.

Blömeke, S., \& Klein, P. (2013). When is a school environment perceived as supportive by beginning mathematics teachers? Effects of leadership, trust, autonomy and appraisal on teaching quality. International Journal of Science and Mathematics Education, 11 (4), 1029-1048.

Brooks, J. S., Hughes, R. M., \& Brooks, M. C. (2008). Fear and trembling in the American high school: Educational reform and teacher alienation. Educational Policy, 22 (1), 45-62.

Chuang, S. C., Cheng, Y. H., Chang, C. J., \& Chiang, Y. T. (2013). The impact of self-confidence on the compromise effect. International Journal of Psychology, 48 (4), 660-675.

Connelly, F. M., \& Clandinin, D. J. (1990). Stories of experience and narrative inquiry. Educational Researcher, 19 (5), 2-14.

Day, C. (2002). School reform and transitions in teacher professionalism and identity. International Journal of Educational Research, 37 (8), 677-692.

Dworkin, G. (1988). The theory and practice of autonomy. Cambridge: University Press.

Govier, T. (1993). Self-trust, autonomy, and self-esteem. Hypatia, 8 (1), 99.

Gwaltney, K. D. (2012). Teacher autonomy in the United States: establishing a standard definition, validation of a nationally representative construct and an investigation of policy affected teacher groups (Doctoral dissertation). University of Missouri, Columbia. 
Audrey PARADIS, Sonja LUTOVAC, Raimo KAASILA. A Canadian teacher's perceived autonomy and self-confidence in the midst of an educational reform

PROBLEMS

OF EDUCATION

IN THE $21^{\text {st }}$ CENTURY

Volume 66, 2015

Hargreaves, A. (2004). Inclusive and exclusive educational change: Emotional responses of teachers and implications for leadership. School Leadership \& Management, 24 (3), 287-309.

Hargreaves, A., \& Goodson, I. F. (1996). Teachers' professional lives: Aspirations and actualities. In I. F. Goodson, \& A. Hargreaves (Eds.), Teachers professional lives (pp. 1-27). London: Falmer Press.

Helgøy, I., \& Homme, A. (2007). Towards a new professionalism in school? A comparative study of teacher autonomy in Norway and Sweden. European Educational Research Journal, 6 (3), 232249.

Ingersoll, R. M. (2001). Teacher turnover and teacher shortages: An organizational analysis. American Educational Research Journal, 38 (3), 499-534.

Kaasila, R. (2007). Using narrative inquiry for investigating the becoming of a mathematics teacher. $Z D M, 39$ (3), 205-213.

Kelchtermans, G. (1996). Teacher vulnerability: Understanding its moral and political roots. Cambridge Journal of Education, 26 (3), 307-323.

Lieblich, A., Tuval-Mashiach, R., \& Zilber, T. (1998). Narrative Research. Reading, Analysis and Interpretation. London: Sage.

Littlewood, W. (1996). "Autonomy": An anatomy and a framework. System, 24 (4), 427-435.

Lutovac, S., \& Kaasila, R. (2010). How to apply the emplotment process using the narrative approach in mathematics education. Didactica Slovenica, 25 (3-4), 92-109.

McGrath, I. (2000). Teacher autonomy. In B. Sinclair, I. McGrath and T. Lamb (Eds.), Learner autonomy, teacher autonomy: Future directions (pp. 100-110). London: Longman.

Morony, S., Kleitman, S., Lee, Y. P., \& Stankov, L. (2013). Predicting achievement: Confidence vs selfefficacy, anxiety, and self-concept in Confucian and European countries. International Journal of Educational Research, 58, 79-96.

Patton, M. Q. (1990). Qualitative evaluation and research methods (2nd ed.). Newbury Park, CA: Sage.

Pearson, L. C., \& Hall, B. W. (1993). Initial construct validation of the teaching autonomy scale. The Journal of Educational Research, 86 (3), 172-178.

Pearson, L. C., \& Moomaw, W. (2005). The relationship between teacher autonomy and stress, work satisfaction, empowerment, and professionalism. Educational Research Quarterly, 29 (1), 38-54.

Perryman, J., Ball, S., Maguire, M., \& Braun, A. (2011). Life in the pressure cooker-school league tables and English and mathematics teachers' responses to accountability in a results-driven era. British Journal of Educational Studies, 59 (2), 179-195.

Polkinghorne, D. E. (1995). Narrative configuration in qualitative analysis. International Journal of Qualitative Studies in Education, 8 (1), 5-23.

Robertson, L., \& Jones, M. G. (2013). Chinese and US middle-school science teachers' autonomy, motivation, and instructional practices. International Journal of Science Education, 35 (9), 1454-1489.

Sachs, J. (2001). Teacher professional identity: Competing discourses, competing outcomes. Journal of Education Policy, 16 (2), 149-161.

Shaw, J. (2008). Teachers working together: What do we talk about when we talk about autonomy? In T. Lamb \& H. Reinders (Eds.), Learner and Teacher Autonomy: Concepts, realities, and response (Vol. 1, pp. 187-203). Amsterdam: John Benjamins Publishing.

Smith, R., \& Ushioda, E. (2009). Autonomy: under whose control. In R. Pemberton, S. Toogood \& A. Barfield (Eds.), Maintaining control: Autonomy and language learning (Vol. 1, pp. 241-253). Hong Kong: University Press.

Spratt, M., Humphreys, G., \& Chan, V. (2002). Autonomy and motivation: which comes first? Language Teaching Research, 6 (3), 245-26.

Strong, L. E., \& Yoshida, R. K. (2014). Teachers' autonomy in today's educational climate: Current perceptions from an acceptable instrument. Educational Studies, 50 (2), 123-145.

Tett, L., \& Maclachlan, K. (2007). Adult literacy and numeracy, social capital, learner identities and selfconfidence. Studies in the Education of Adults, 39 (2), 150-167.

Yu-hong, J., \& Ting, M. (2012). A review of the research on language teacher autonomy. Sino-US English Teaching, 9 (4), 1045-1055. 
Audrey PARADIS, Sonja LUTOVAC, Raimo KAASILA. A Canadian teacher's perceived autonomy and self-confidence in the midst of an educational reform

$$
\begin{array}{l|l}
\text { Advised by Dalia Augiene, Siauliai University, Lithuania } & \begin{array}{l}
\text { PROBLEMS } \\
\text { OF EDUCATION } \\
\text { IN THE 21 } 1^{\text {st }} \text { CENTURY } \\
\text { Volume 66, 2015 }
\end{array} \\
\end{array}
$$

Received: May 10, 2015

Accepted: July 26, 2015

Audrey Paradis

M. Ed. Doctoral Student, Faculty of Education, University of Oulu, P.O. Box 2000, FI-90014 Oulu, Finland.

E-mail: audrey.paradis@student.oulu.fi

Website: http://www.oulu.fi/edu/

Sonja Lutovac

PhD, Post doc Researcher, Faculty of Education, University of Oulu, P.O. Box 2000, Fl-90014 Oulu, Finland.

E-mail: sonja.lutovac@triera.net

Website: http://www.oulu.fi/edu/

Raimo Kaasila

PhD, Professor, Faculty of Education, University of Oulu, P.O. Box 2000, FI90014 Oulu, Finland.

E-mail: raimo.kaasila@oulu.fi

Website: http://cc.oulu.fi/ rkaasila/ 